\title{
Fulfilling the Promise of Renewable Energy: A Look at the Future
} Mimporatifines

\section{Energy 2050: The Future of Renewable Energy}

\author{
June 21, 2005
}

Dr. Dan E. Arvizu

Director, National Renewable Energy Laboratory 


\section{Energy Challenges are Enormous}

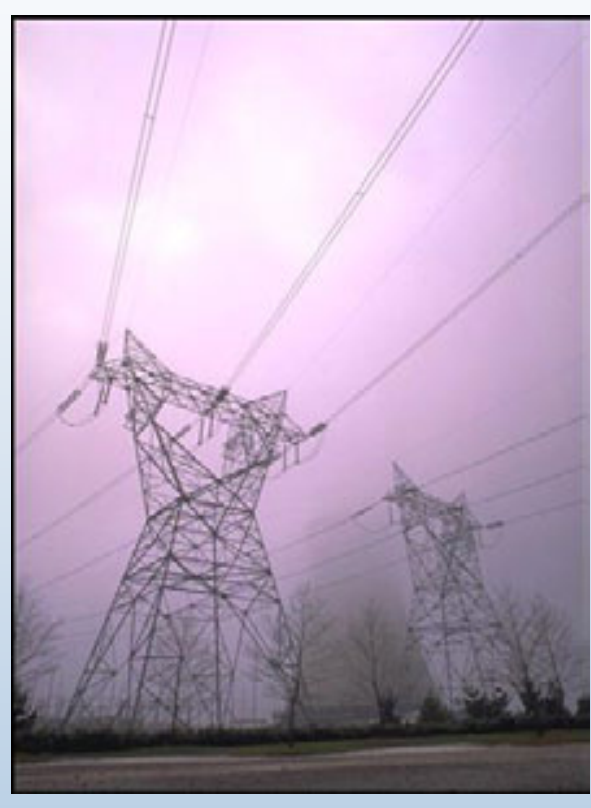

Energy Security and Reliability

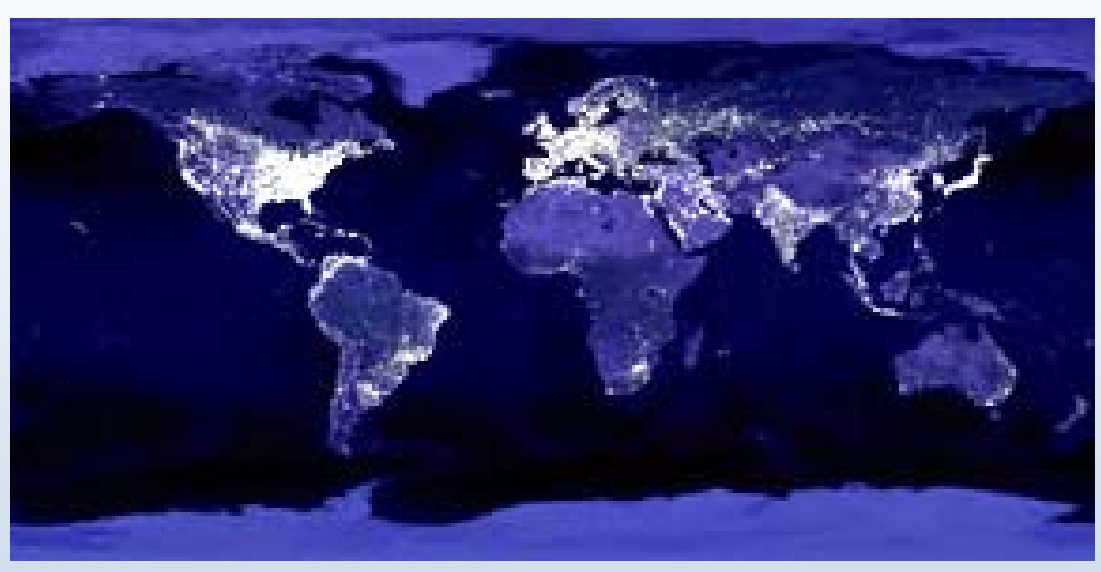

Economic Growth

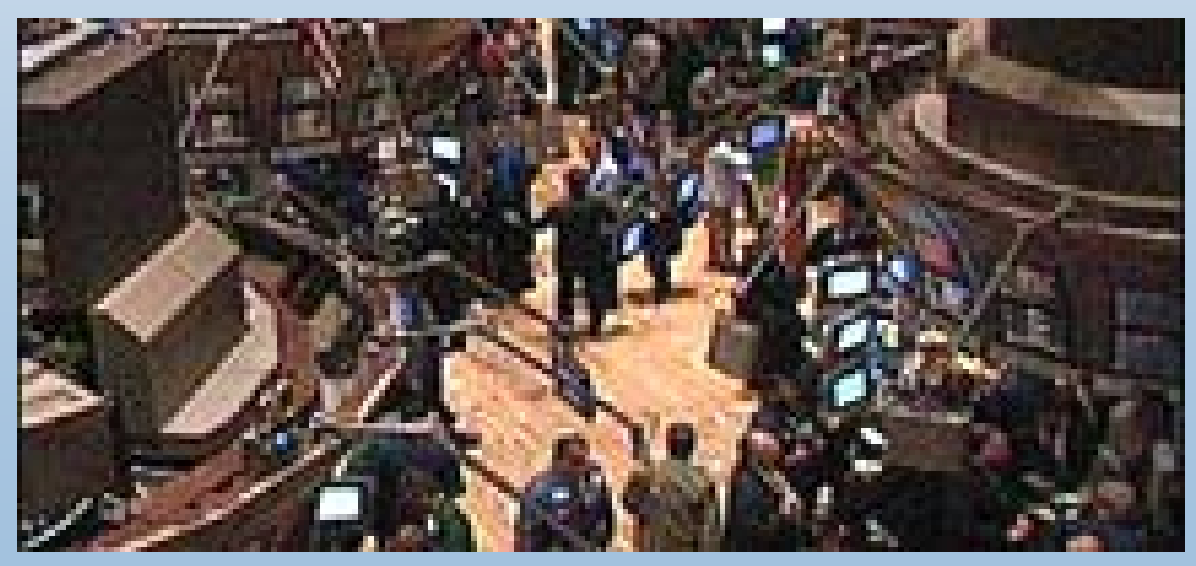

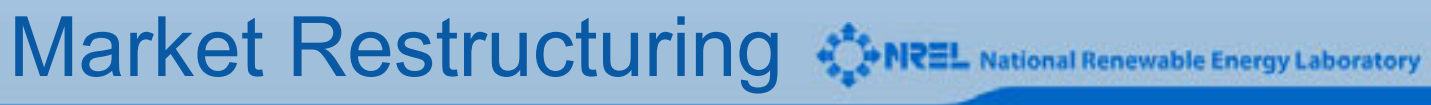

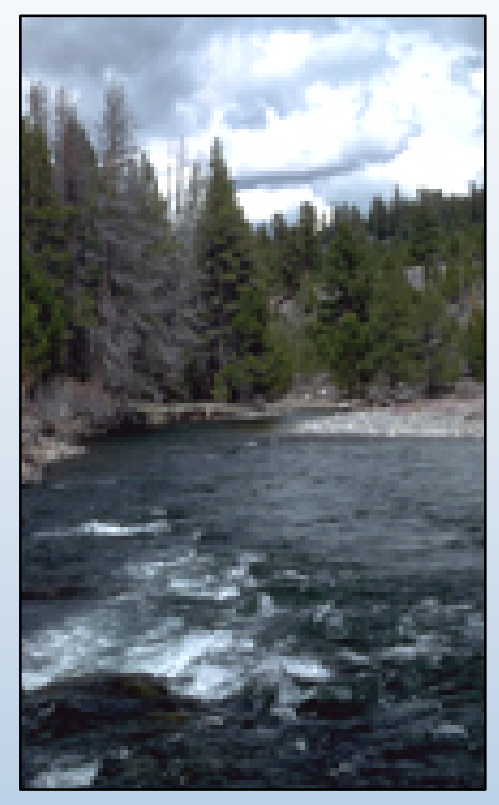

Environmental Impact 


\section{Worldwide Energy Consumption by Source}

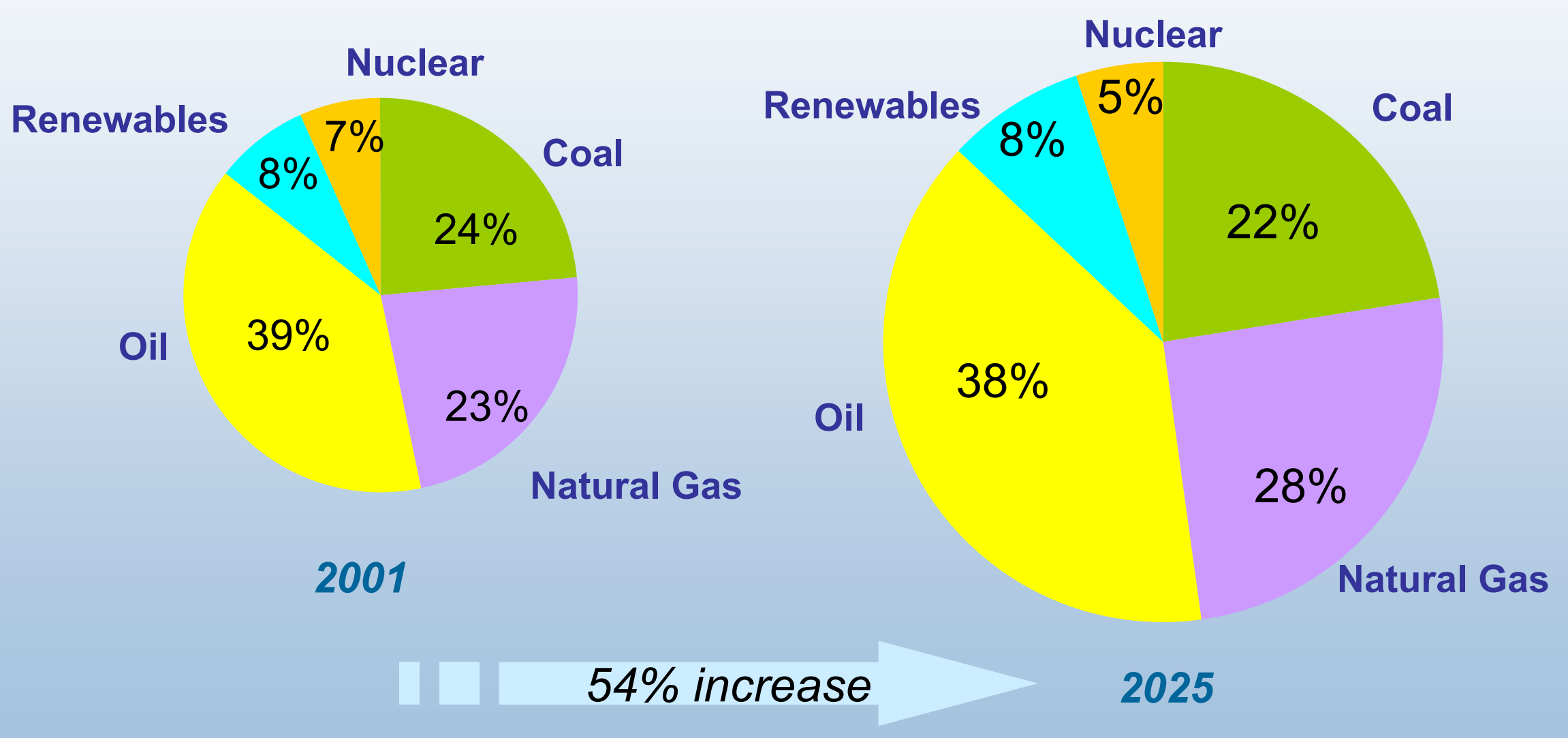




\section{Electricity Outlook: 2001-2025}

\section{$74 \%$ increase}

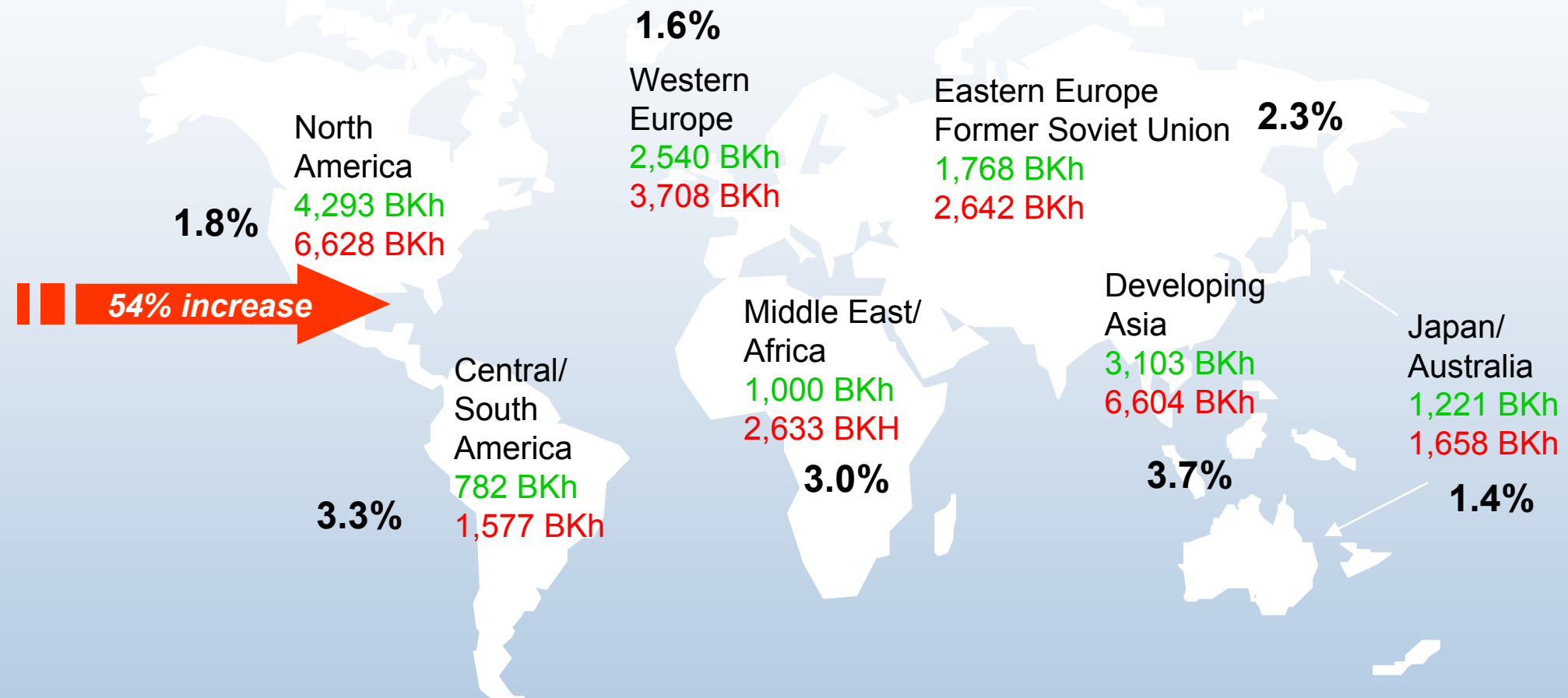

- Total annual average world electricity growth - $2.4 \%$ from 2001 to 2025

- Growth rates in transitioning economies higher than developed economies

- Natural gas and coal will be near-term fuels of choice for generation

- Distributed generation and renewable may offer attractive options 


\section{U.S. Energy Consumption by Source}

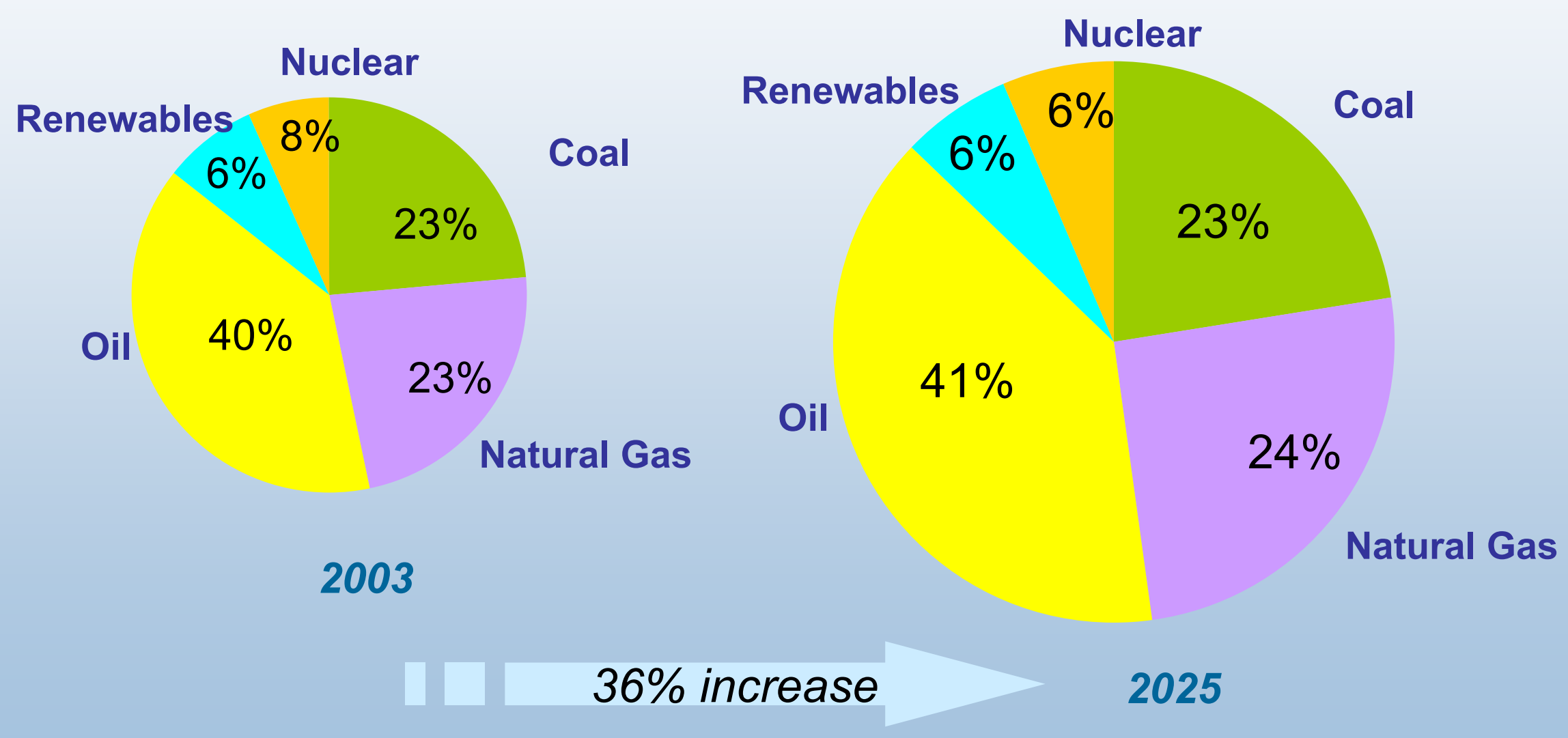




\section{The Role of Renewables in the U.S. Energy Supply - 2003}

Petroleum

$39 \%$

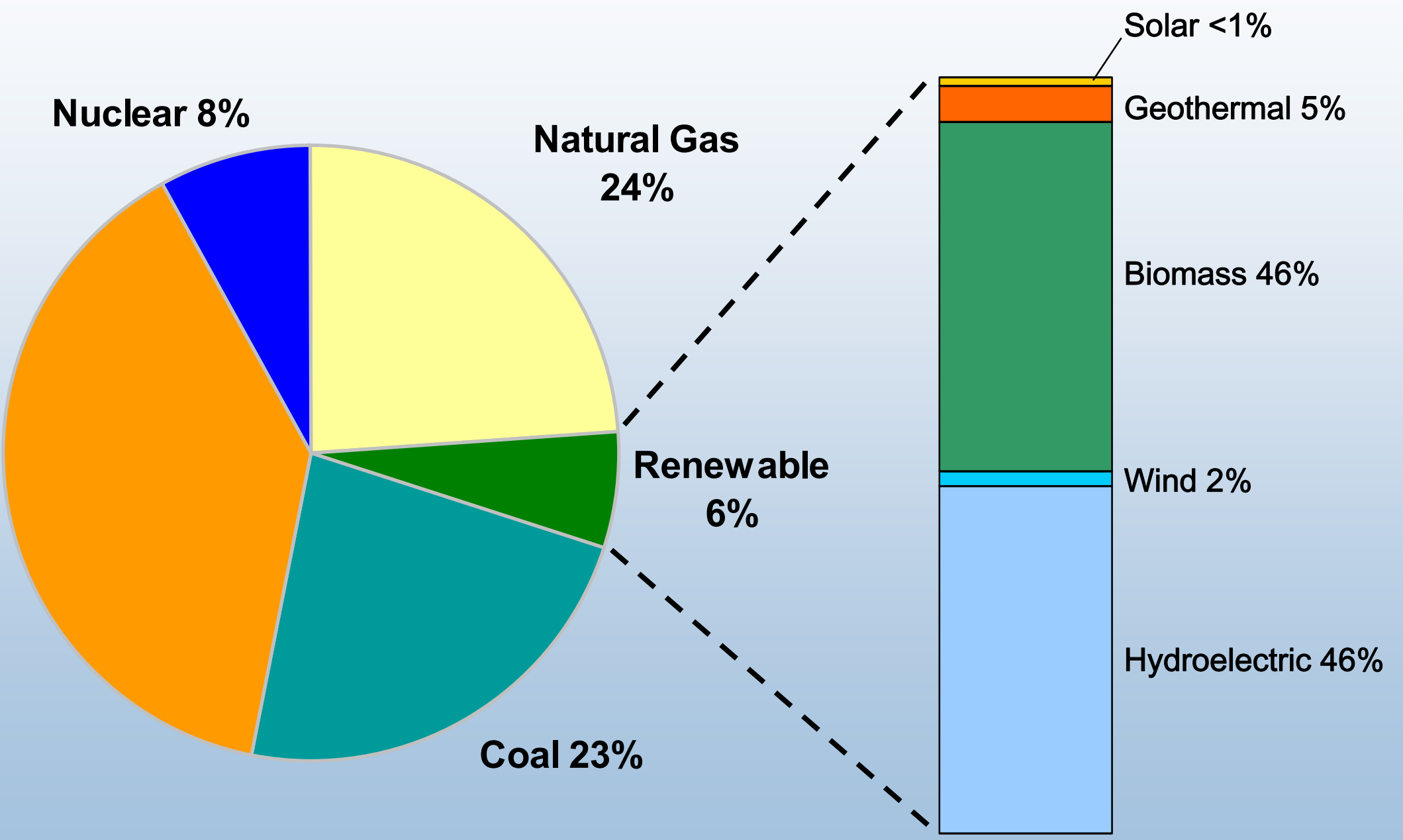




\section{U.S. Energy Flows}

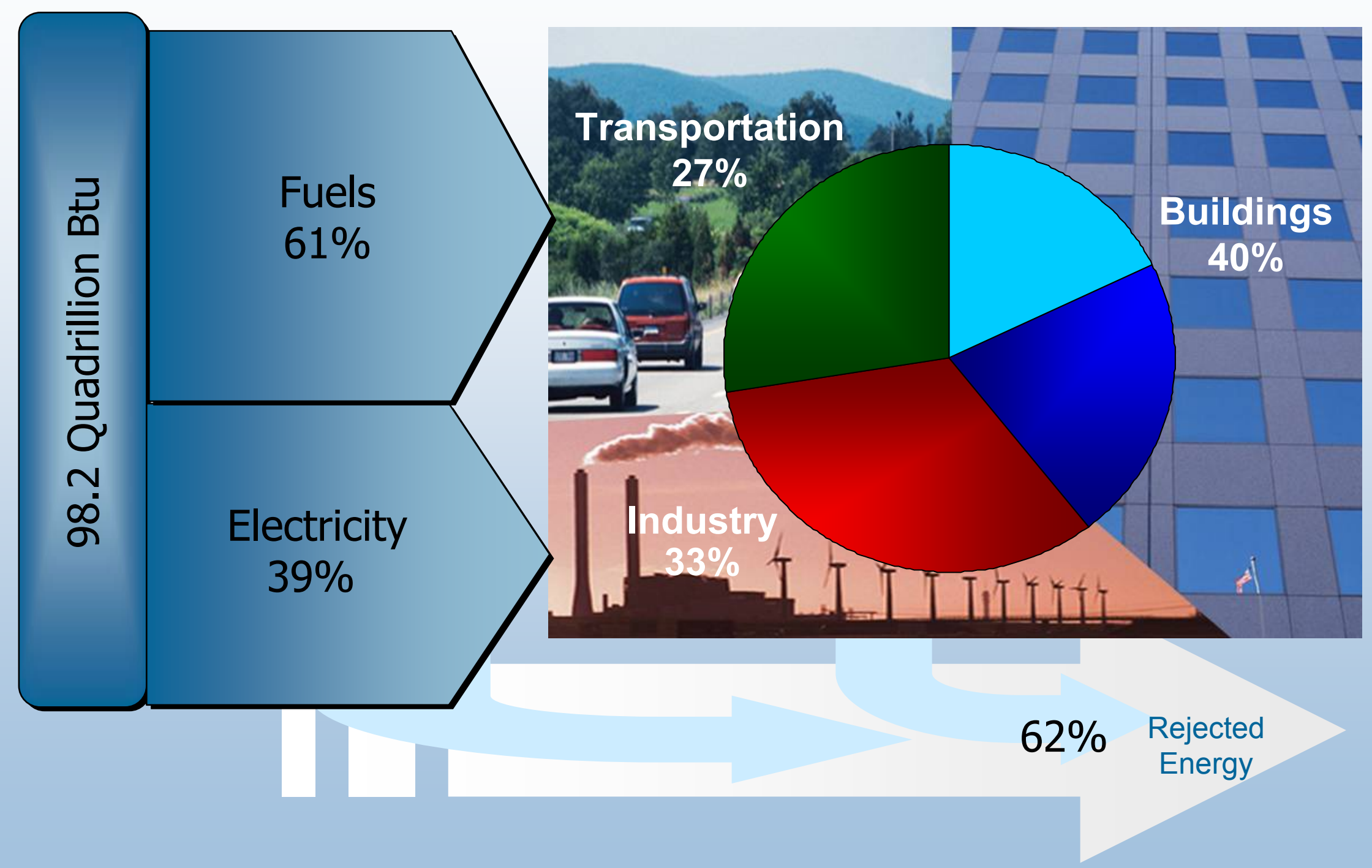




\section{Technology-based Solutions: There is no one silver bullet, we need many}

- Energy efficiency

- Renewable energy

- Non-polluting transportation fuels

- Separation and capture of $\mathrm{CO}_{2}$ from fossil fuels

- Next generation of nuclear fission and fusion technology

- Transition to smart, resilient, distributed energy systems coupled with pollution-free energy carriers, e.g. hydrogen and electricity

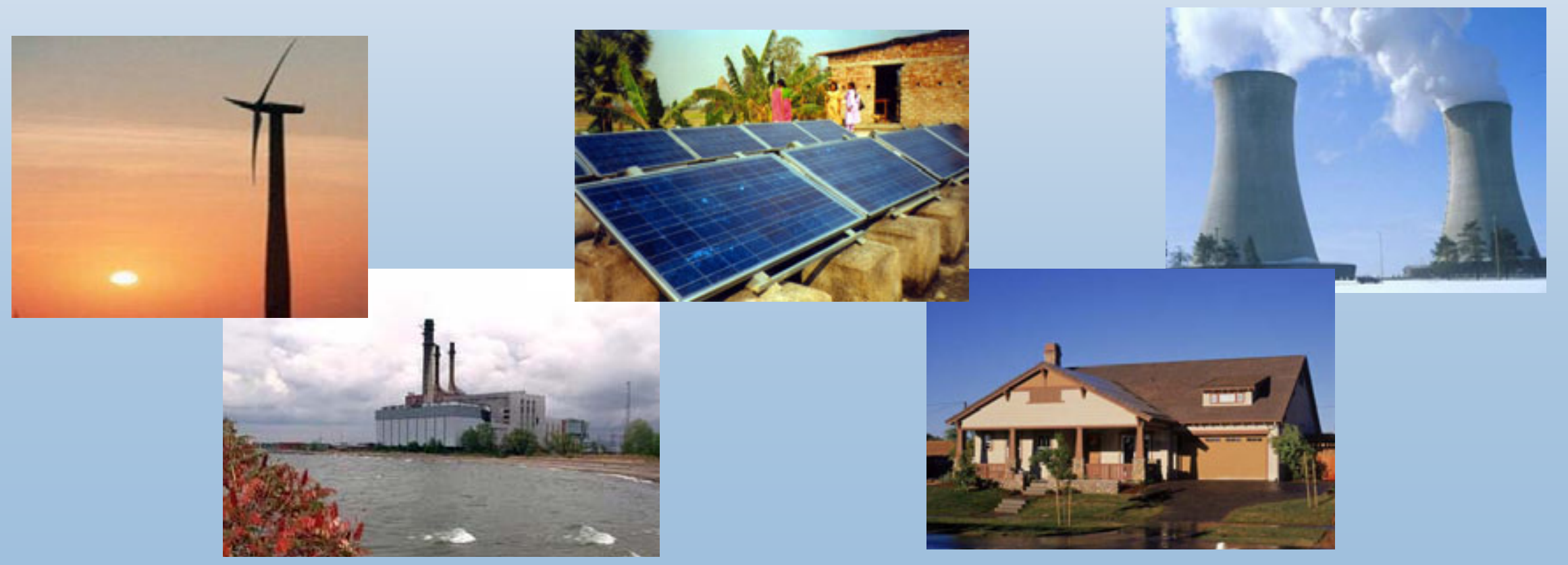




\section{Renewable Energy Must Play a Key Role in a More Diverse and Secure Energy Supply}

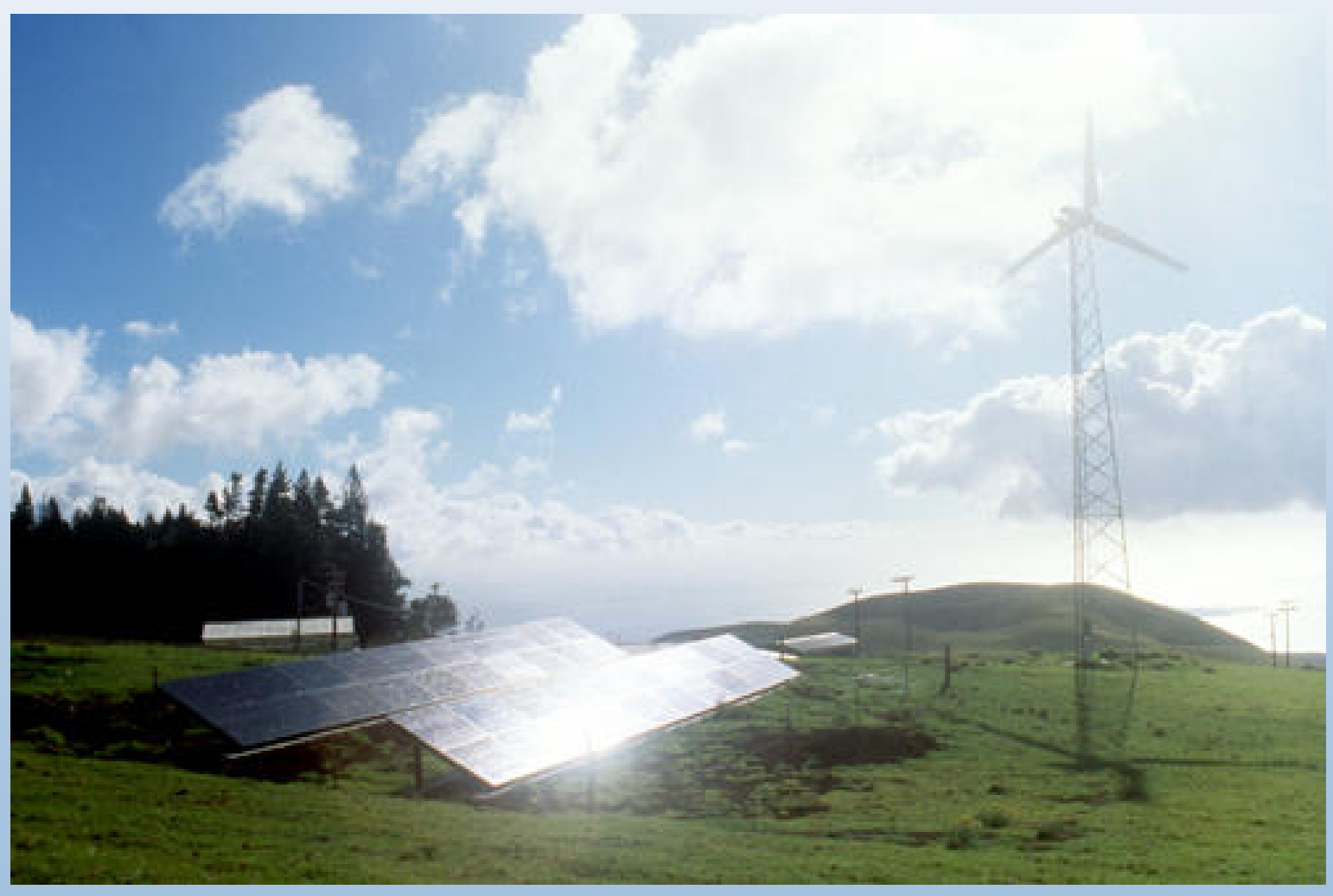




\section{Wind Energy Status}

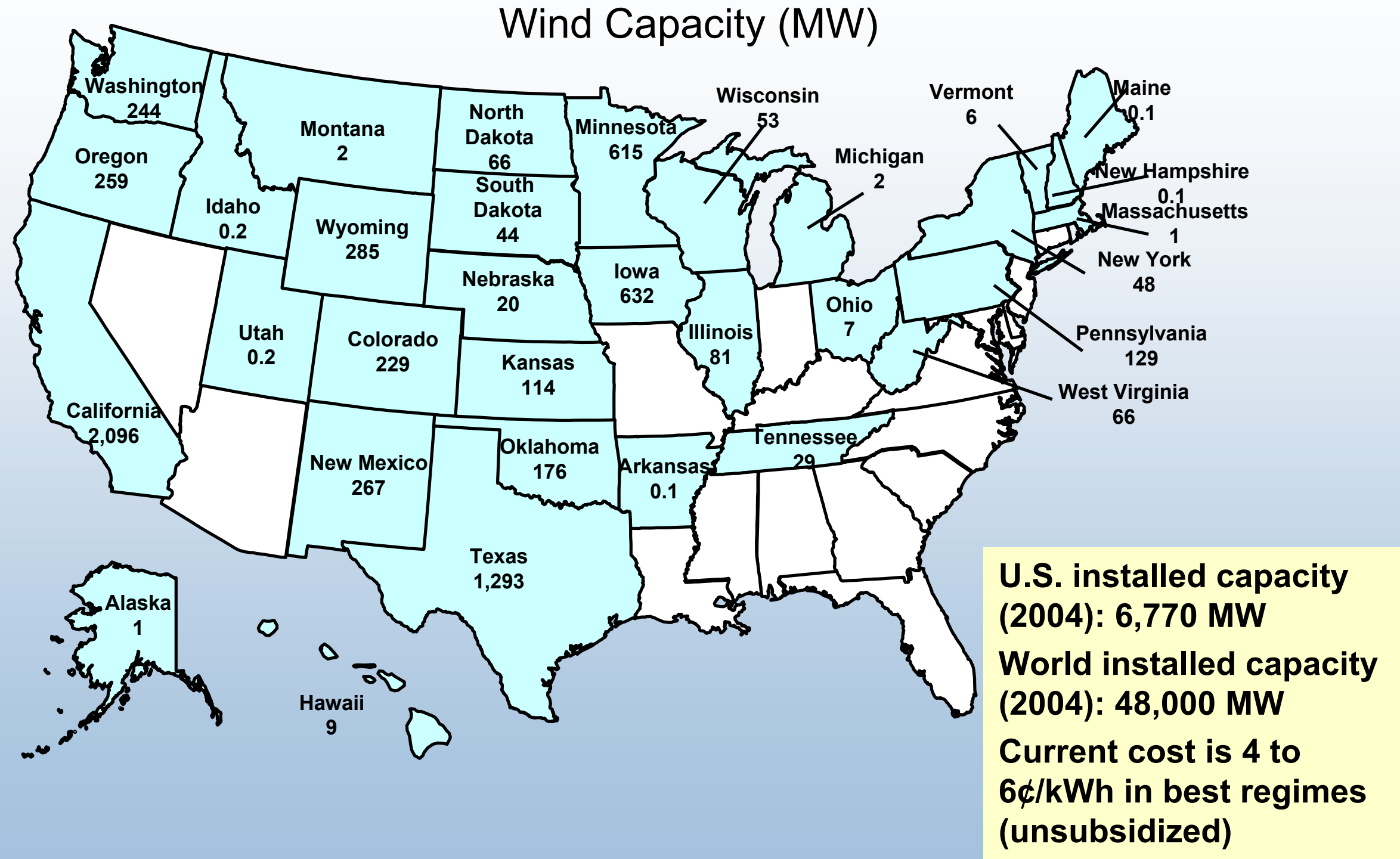

Source: Worldwatch Institute 


\section{Solar Energy Status}

- Concentrating Solar Power

- Nine parabolic trough plants

- 12-14ф/kWh

- Photovoltaics

- Price of power from grid connected PV systems is 20 to $30 \phi / \mathrm{kWh}$

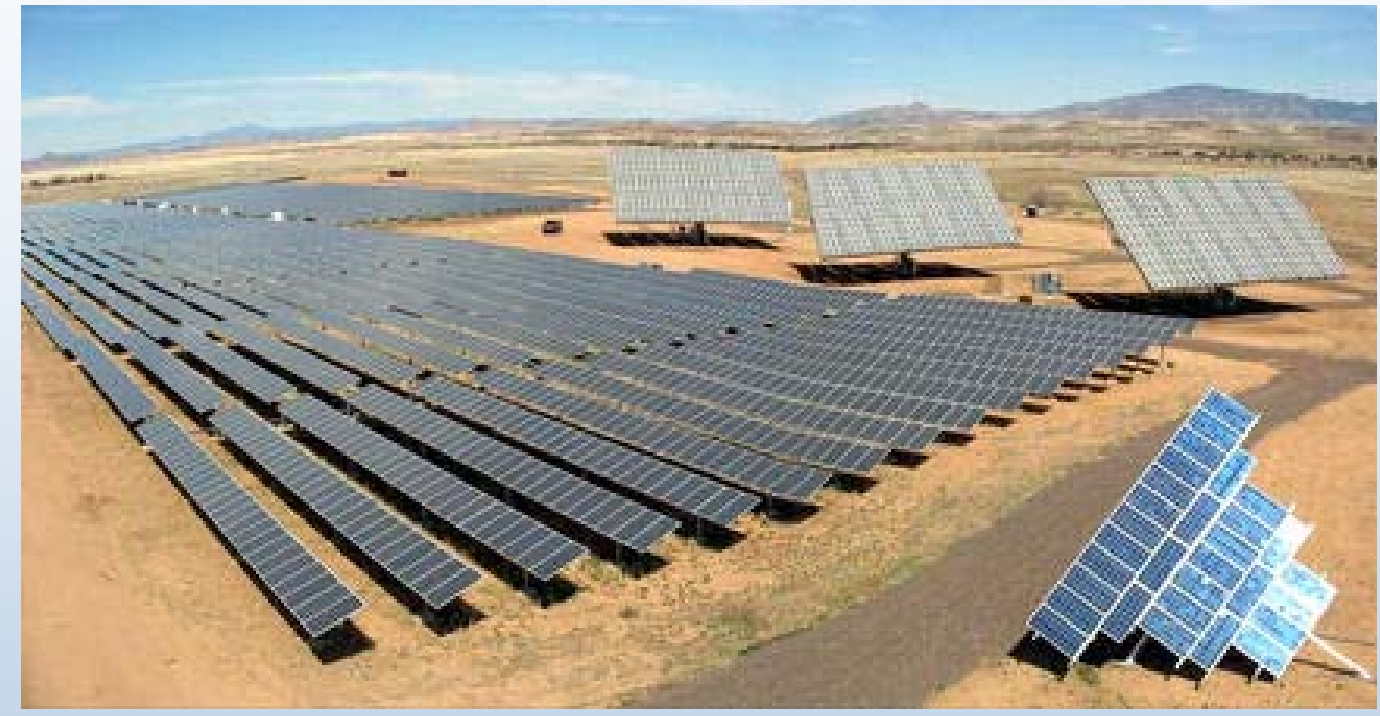

PV systems at the Arizona Public Service facility in Prescott, Arizona

U.S. installed capacity (2004) - PV and solar thermal: 0.5 GW World capacity (2004):

- Solar PV, grid-connected: 1.8 GW

- Solar PV, not grid-connected: 2.2 GW 


\section{Biomass/Biofuels Status}

\section{Biopower}

- Grid-connected capacity

- $9700 \mathrm{MW}$ direct combustion

- $400 \mathrm{MW}$ co-firing

- Biopower electricity prices generally range from $8-12 \phi / \mathrm{kWh}$

\section{Biofuels}

- Biodiesel - 15 million gallons (2002)

- Corn ethanol

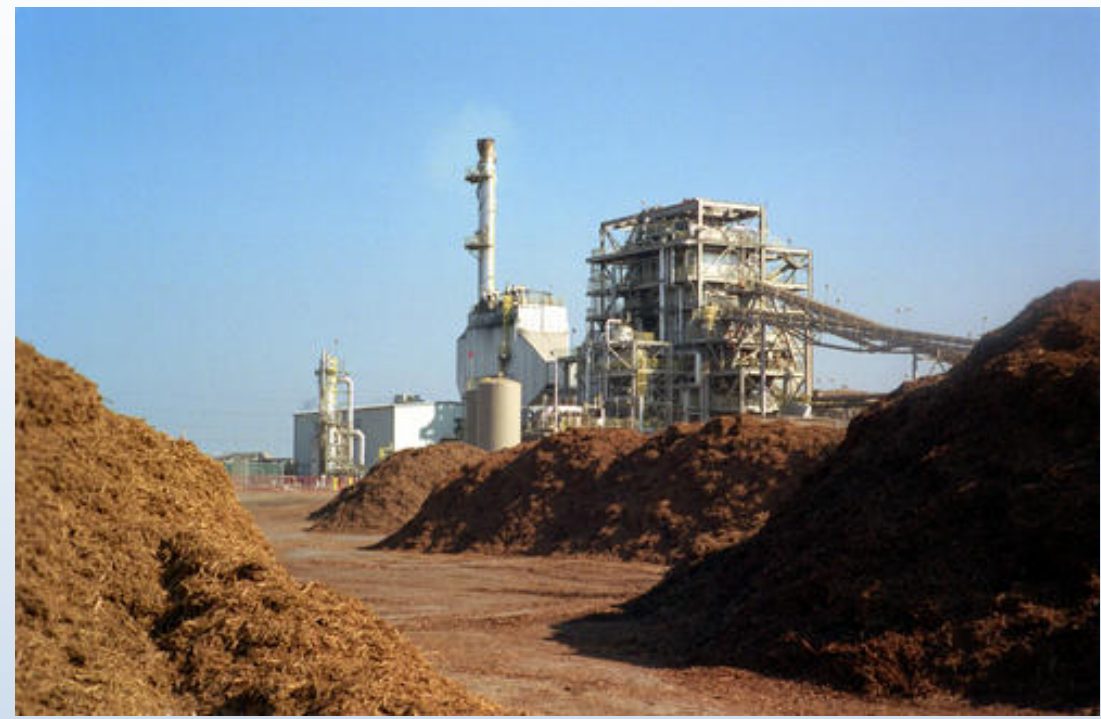

Rated at $21 \mathrm{MW}$ and providing the San Francisco Bay Area with baseload capacity, the Tracy Biomass Plant uses wood residues discarded from agricultural and industrial operations.

- 81 commercial plants

- 3.4 billion gallons (2004)

- $\sim \$ 1.22 / \mathrm{gal}$

- Cellulosic ethanol*

- \$2.73/gal

- World biomass electricity capacity (2004): 36 GW

- World biofuels production capacity (2004): ethanol 32 billion I/yr; biodiesel 2.2 billion I/yr

Source: Worldwatch Institute

${ }^{*}$ Not commercially available 


\section{Factors Inhibiting Pace and Volume of Renewable Energy Market Entrance}

\section{RISK REDUCTION}

- Consistent \& predictable policies

- Continued advanced technology development

- Enabling market viability

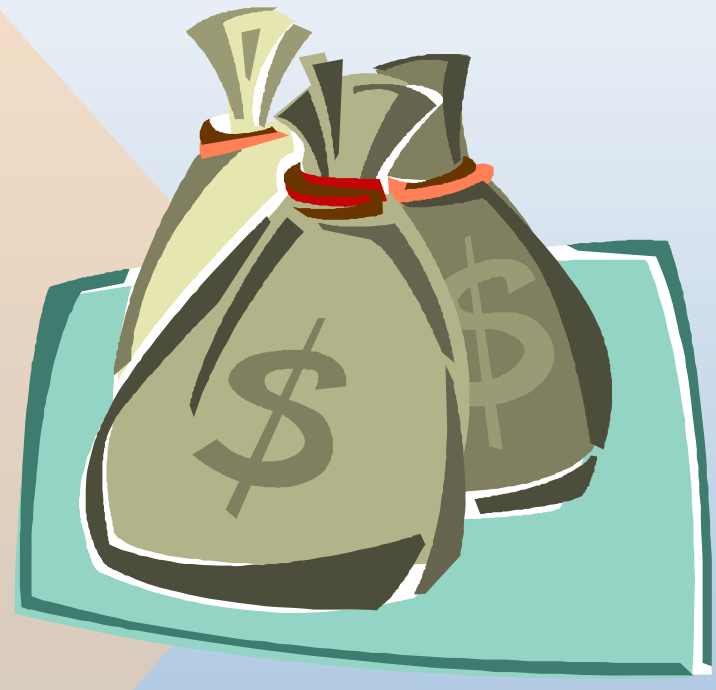

CAPITAL

MOBILIZATION 


\section{Current Federal Energy Legislative Proposals*}

- Production tax credit extension

- Solar investment tax credits for residential and commercial property

- Tax credits for fuel cell, hybrid, biodiesel and alternative fuel vehicles

- Renewable energy portfolio standards 


\section{State Policies are Opening Markets for Renewable Energy}
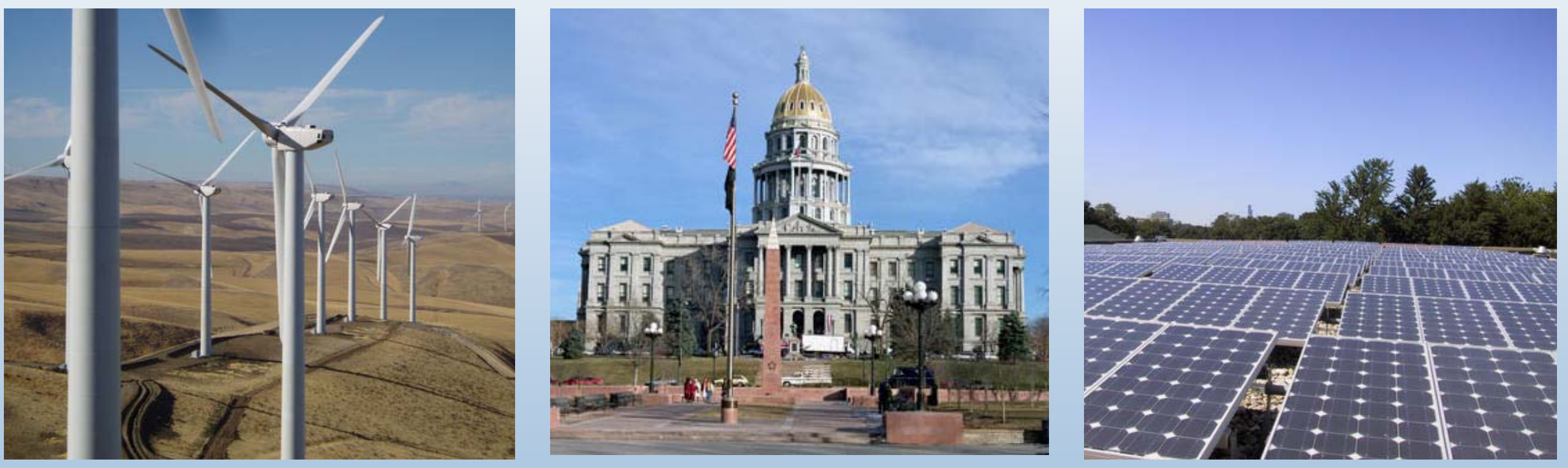


\section{Renewable Electricity Standards}

Nevada: $15 \%$ by 2013 , solar $5 \%$ of annual

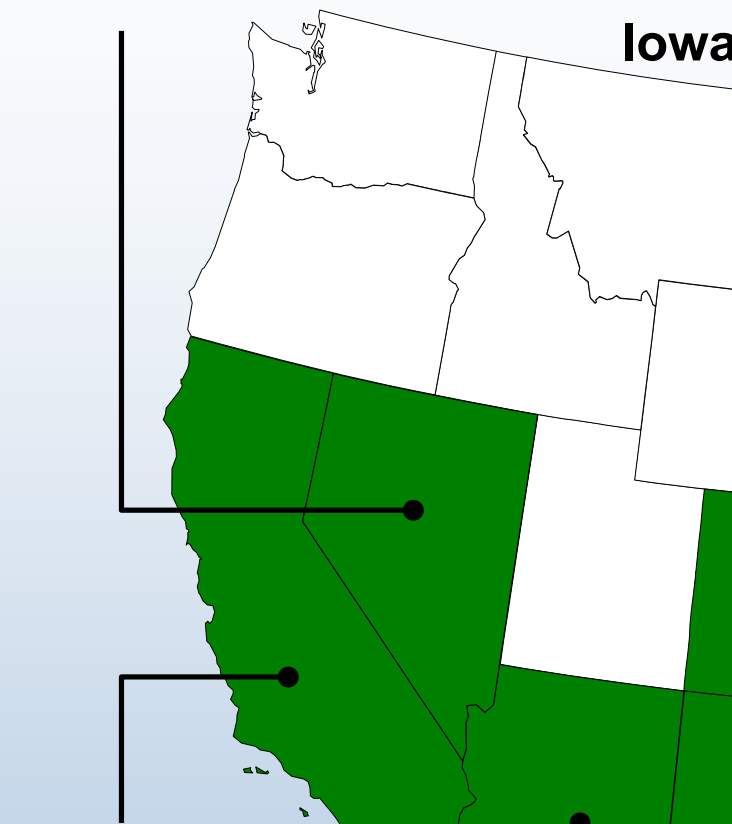

\section{California:} $20 \%$ by 2017

Arizona: $1.1 \%$ by $2007,60 \%$ solar

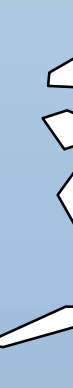

Minnesota: $19 \%$ by $2015^{*}$ owa: 2\% by 1999
New York:

$24 \%$ by 2013

Wisconsin:

$2.2 \%$ by 2011
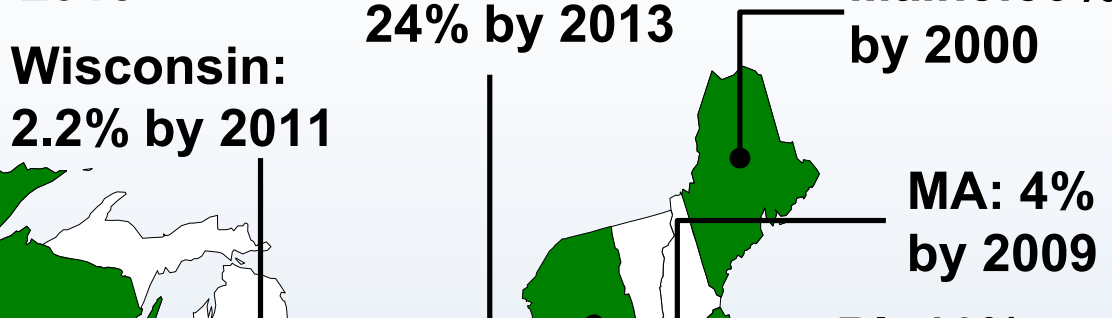

RI: $16 \%$

by 2019

CT: $10 \%$ by 2010 NJ: $6.5 \%$ by 2008 Maryland: 7.5\% by 2019 Washington D.C: $11 \%$ by 2022 Pennsylvania: $8 \%$ by 2020

Texas:

New Mexico: $10 \%$ by 2011
$2.7 \%$ by 2009

Colorado: $10 \%$ by 2015 


\title{
There is Regional Interest in Promoting Clean Energy
}

\author{
Western Governors' Association \\ Clean and Diversified Energy Initiative
}

- Western U.S is rich with fossil, hydro and renewable energy resources.

- Goal of 30,000 MW of clean energy by 2015 , using solar, wind, geothermal, biomass, clean coal technologies and advanced natural gas technologies.

- Goal to increase energy efficiency by $20 \%$ by 2020 .

- Meet the West's generation and transmission needs over the next 25 years. 


\section{What Are Some of the Issues?}

- Valuing externalities

- Connectivity to the grid

- Challenges in current regulatory environment

- Transmission capacity

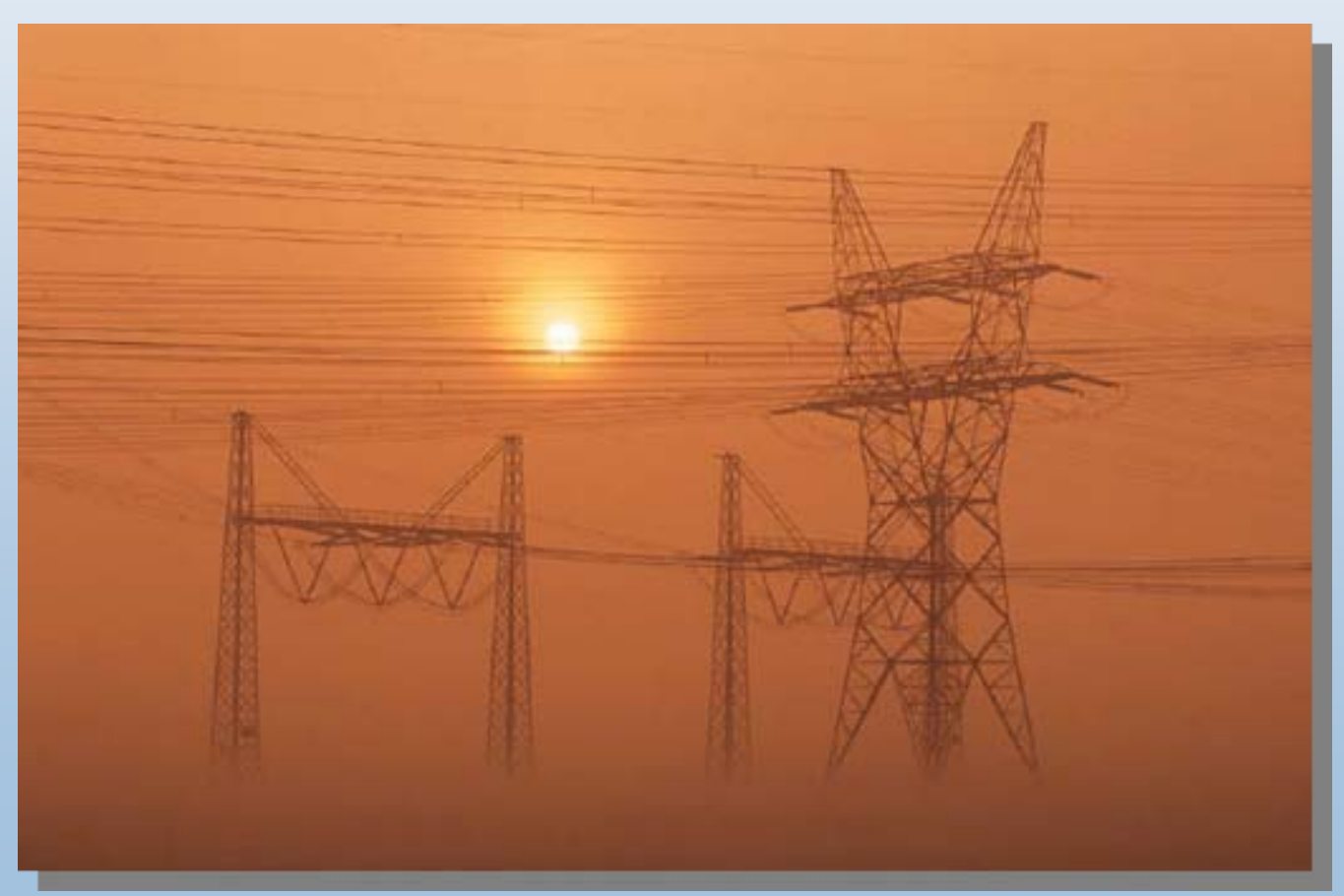




\section{Worldwide Renewable Resources Potential: Meeting the RE Challenge Depends Heavily on Solar}

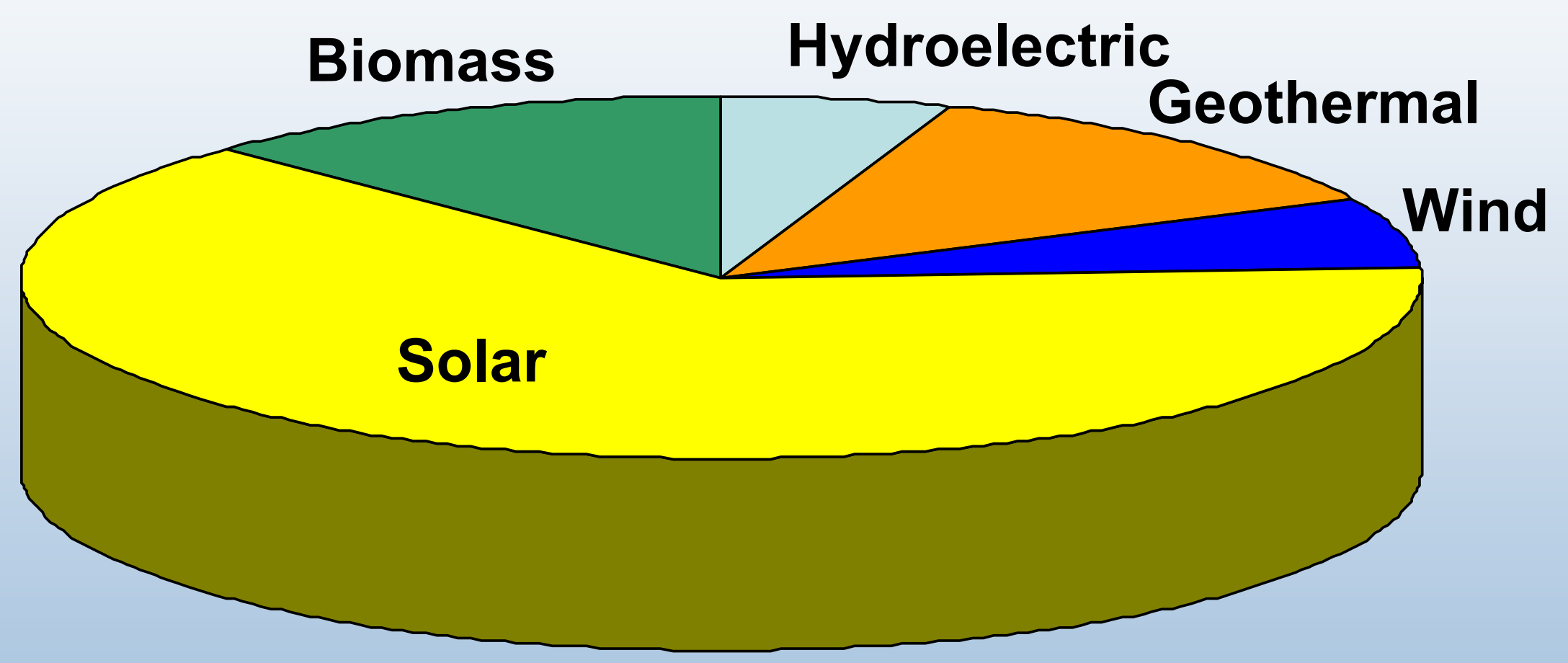

Far exceeds today's world energy consumption 


\section{The Future for Renewable Energy: A Technology Outlook}
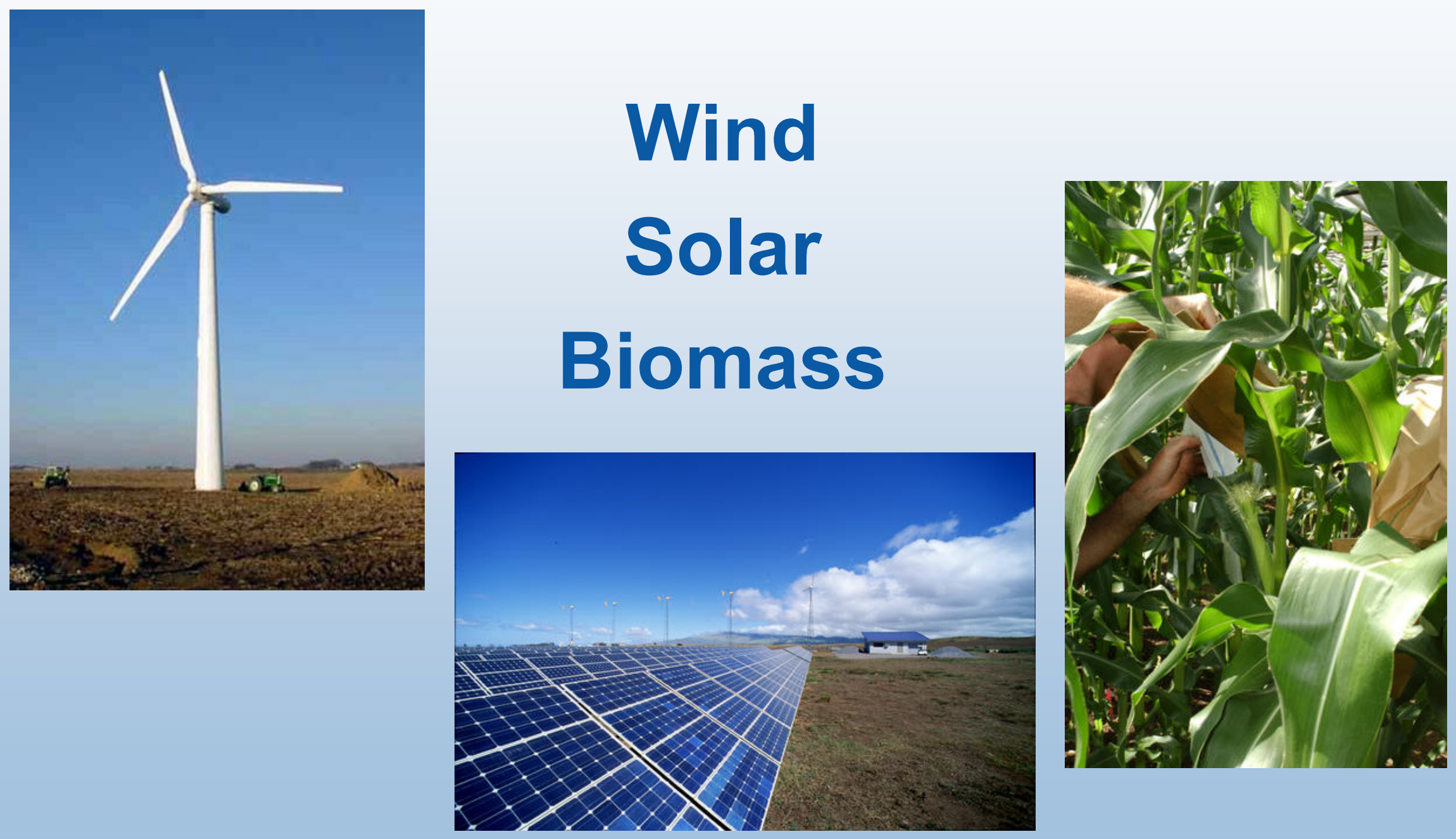


\section{Renewable Energy Costs are Decreasing}

Levelized cents/kWh in constant $\$ 2000^{1}$
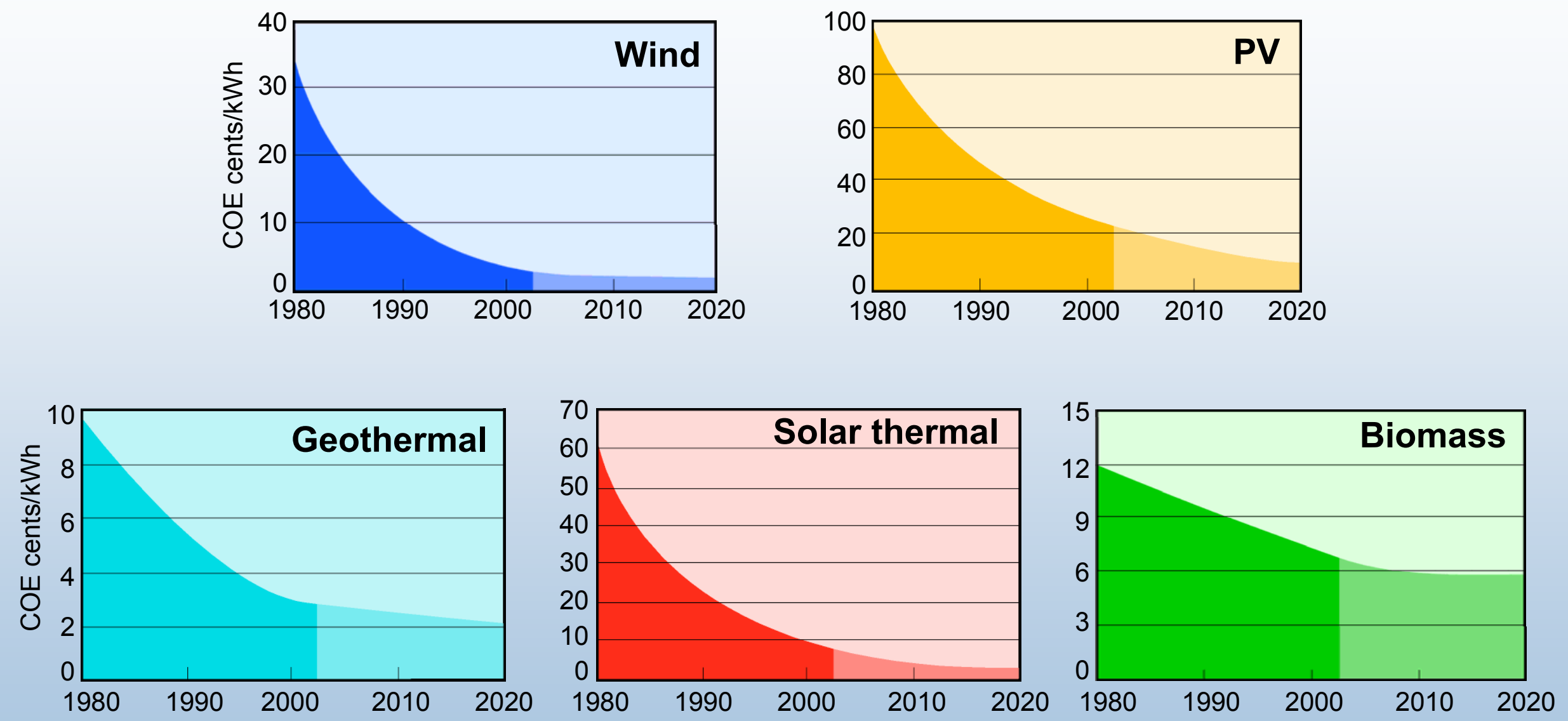

Source: NREL Energy Analysis Office (www.nrel.gov/analysis/docs/cost_curves_2002.ppt)

${ }^{1}$ These graphs are reflections of historical cost trends NOT precise annual historical data.

Updated: October 2002 


\section{Wind Outlook}

DOE Wind Program R\&D goals:

- $3 \phi / \mathrm{kWh}^{*}$ in class $4+$ wind areas onshore

- $5 \phi / \mathrm{kWh}^{*}$ for offshore systems

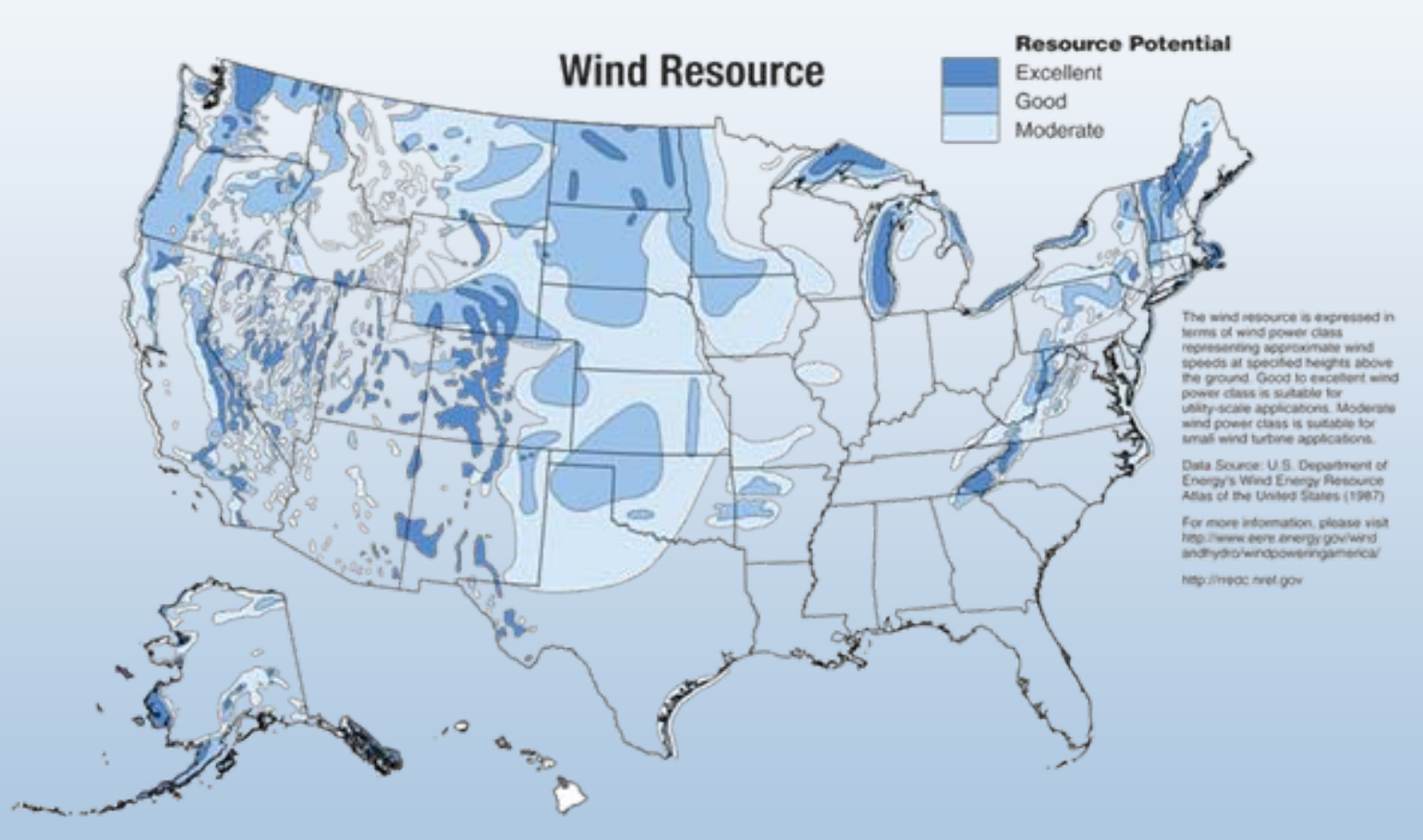

* unsubsidized 


\section{THE EVOLUTION OF COMMERCIAL U.S. WIND TECHNOLOGY}

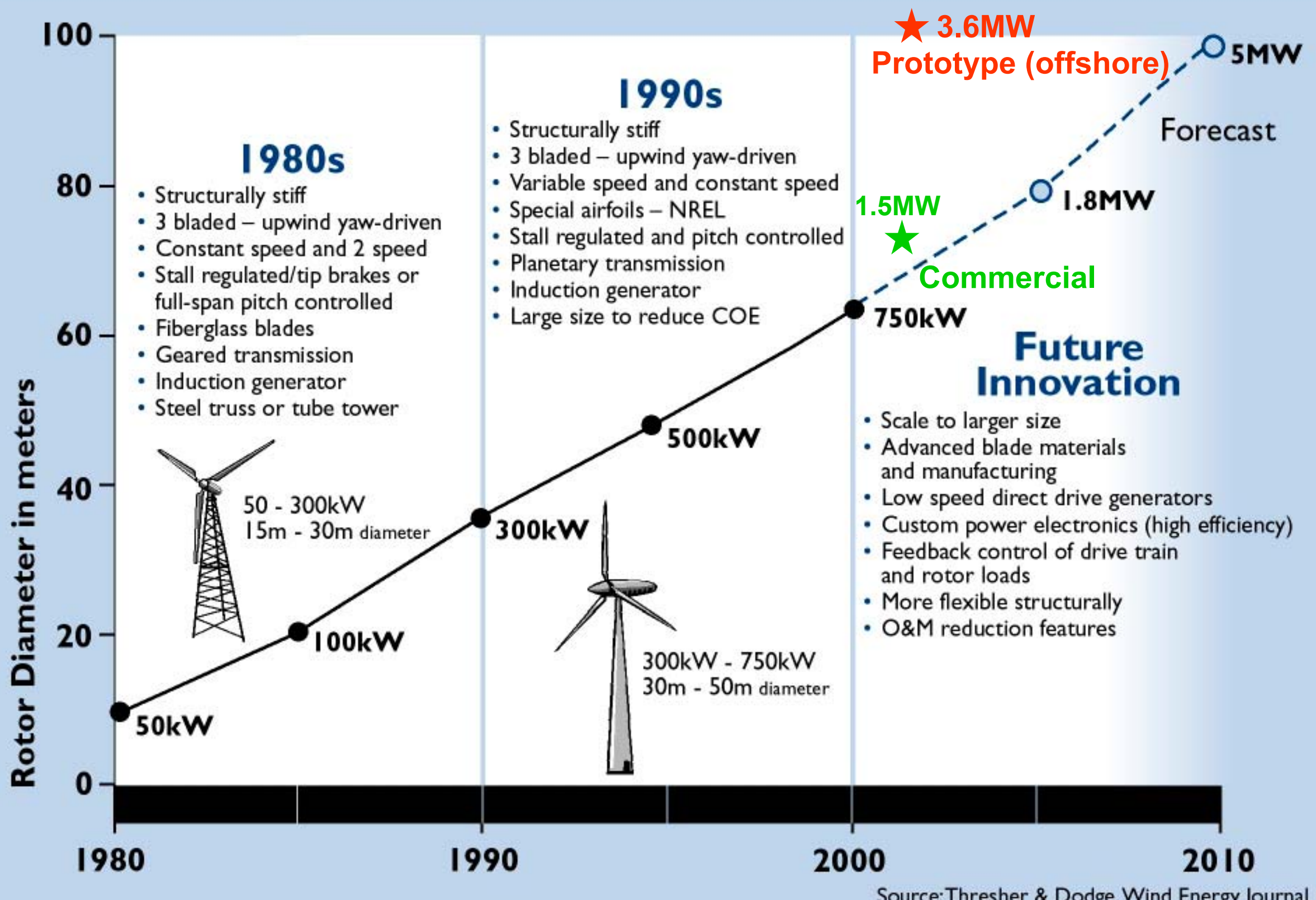

Source:Thresher \& Dodge,Wind Energy Journal 1998 


\section{Solar Outlook}

DOE Solar Program goals

- Photovoltaics: 6ф/kWh by 2020

- Concentrating solar power/troughs: $5 \phi / \mathrm{KWh}$ by 2012

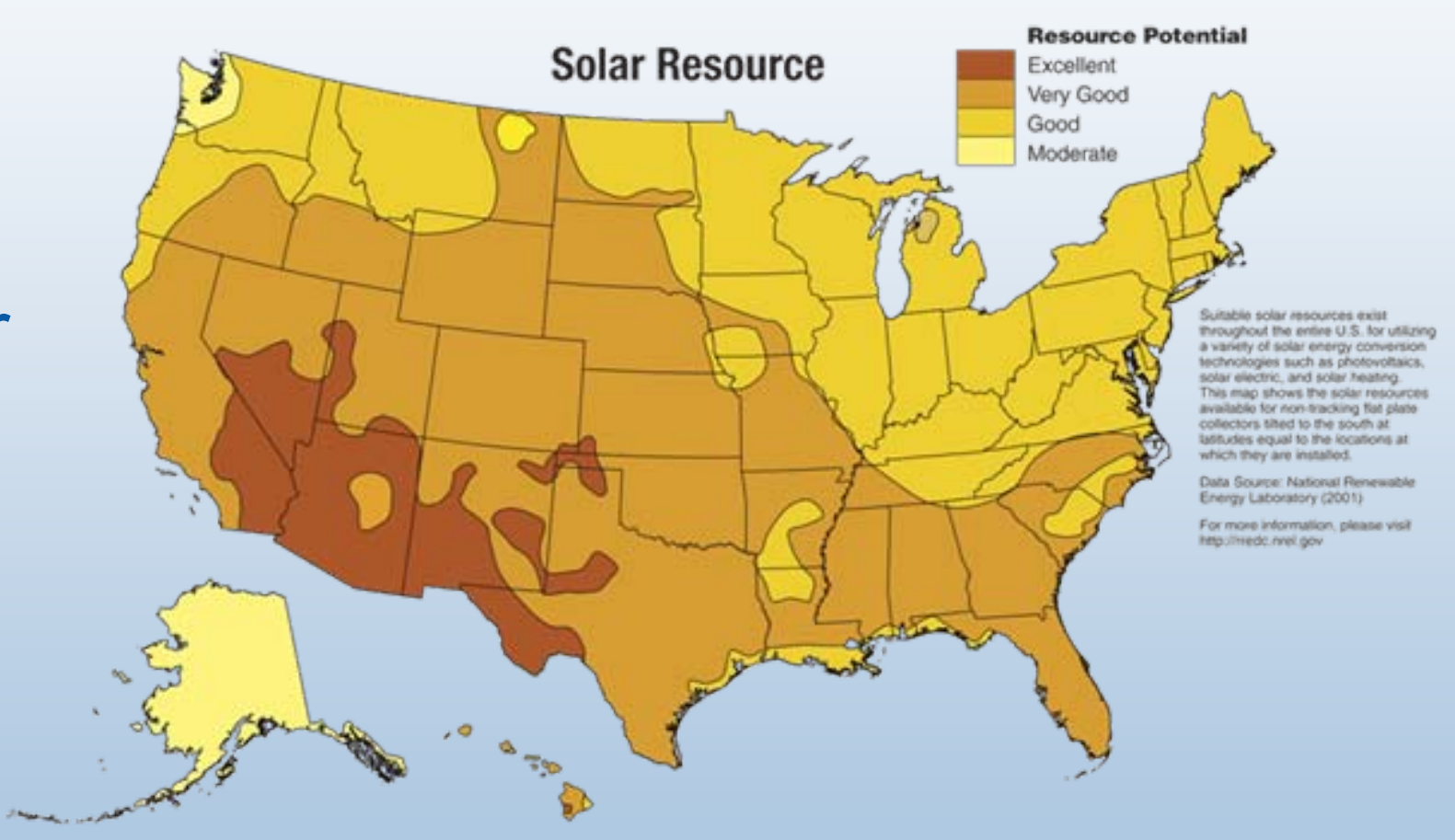




\section{Cost/Efficiency of Photovoltaic Technology}

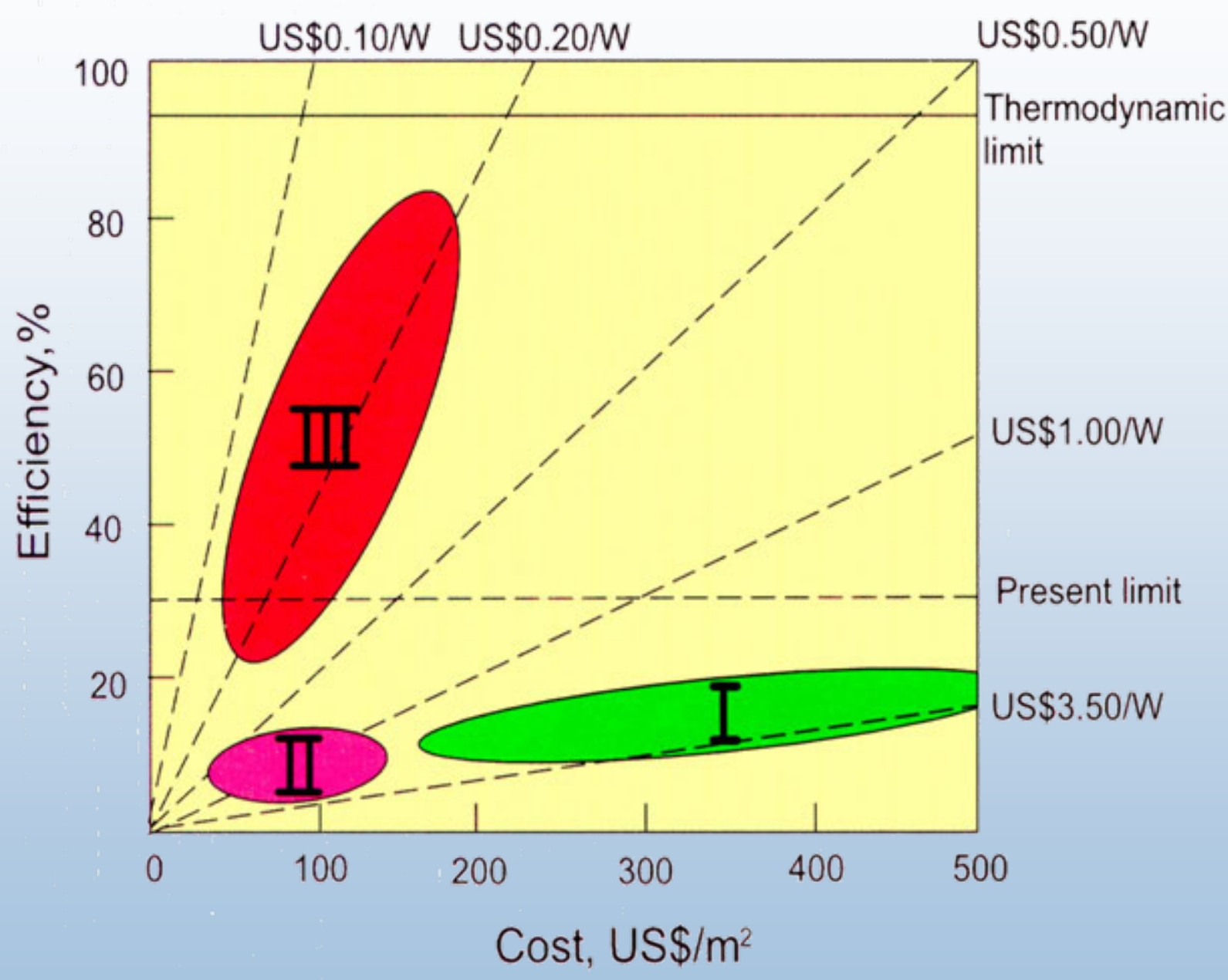

Future Technology Directions

- Research on crystalline silicon, thin films, and balance-ofsystems components

- Higher-risk, longerterm R\&D for all system components that can leapfrog beyond today's technology

Costs are modules per peak W; installed is $\$ 5-10 / \mathrm{W} ; \$ 0.35-\$ 1.5 / \mathrm{kW}-\mathrm{hr}$ 


\section{Biomass/Biofuels Outlook}

DOE Biomass Program goals:

- Competitive electricity by 2020

DOE Biofuels Program goals:

- Produce ethanol cheaply from lignocellulose resources - agriculture \& forestry

- Use of biology together with thermo-chemistry

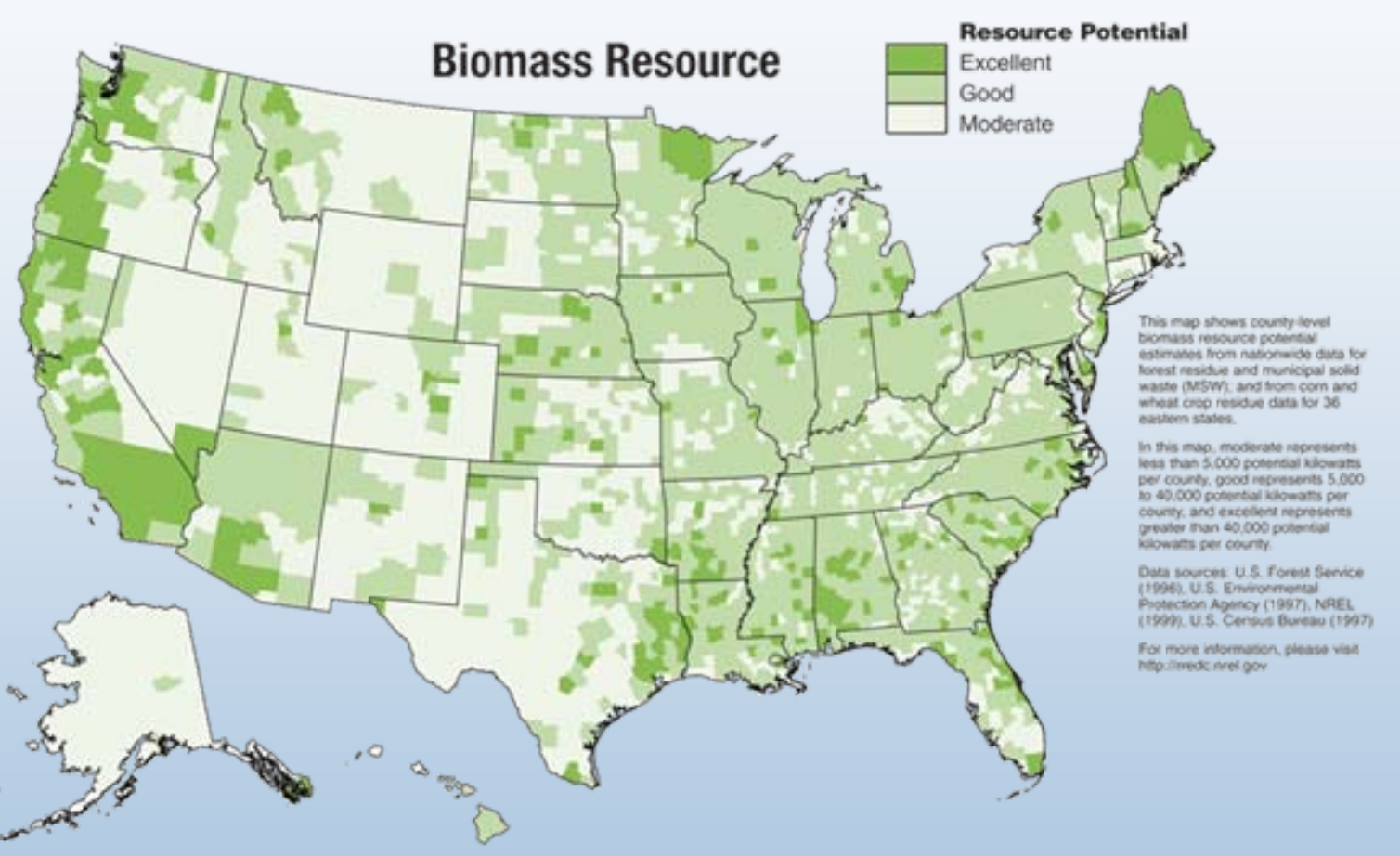

- Target: $\$ 1.07 /$ gal by 2020 


\section{Biomass Technology Advances}

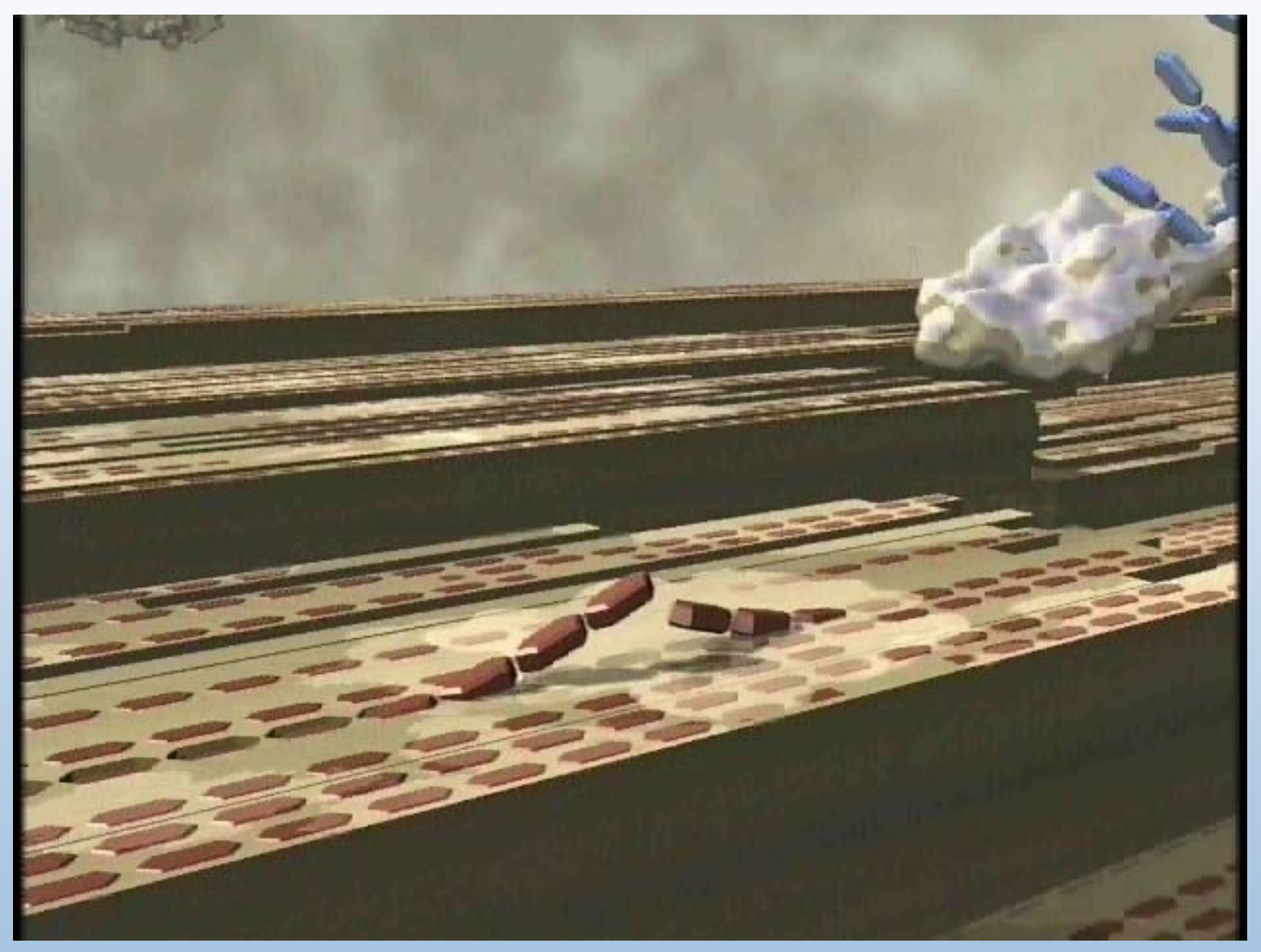

Future Technology Directions

- Plant cell wall deconstruction

- Robust ethanologens

- Better options for thermochemical fuels

- Process intensification 


\section{Industry Market Viability}

E.

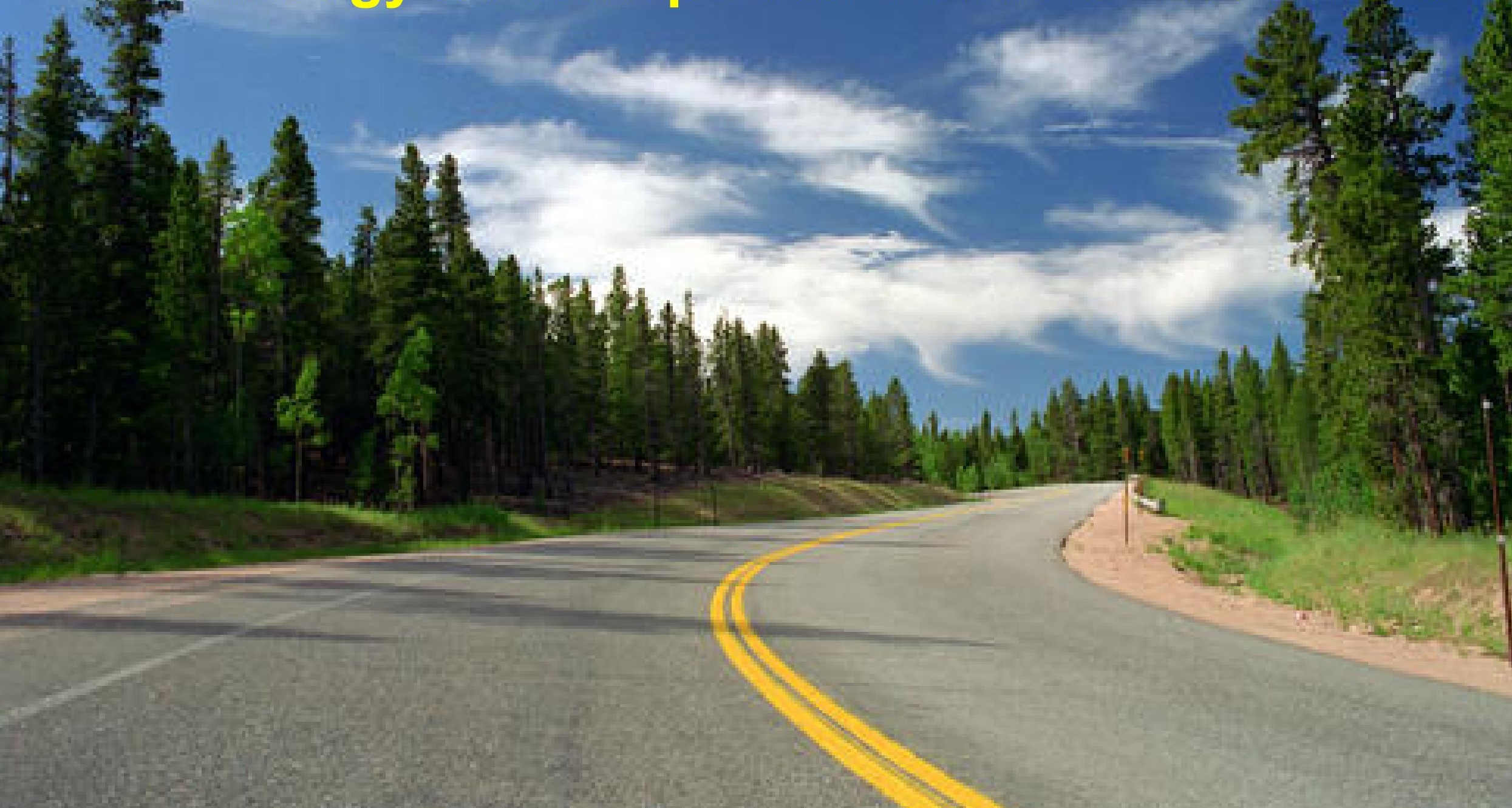


A Future Vision for Wind Energy Markets

\begin{tabular}{|c} 
Today \\
2005 \\
Bulk Power \\
Generator \\
$4-6 \phi$ at 15mph \\
- Land Based \\
• Bulk Electricity \\
• Wind Farms \\
Future Potential= \\
20\% of \\
Electricity Market
\end{tabular}

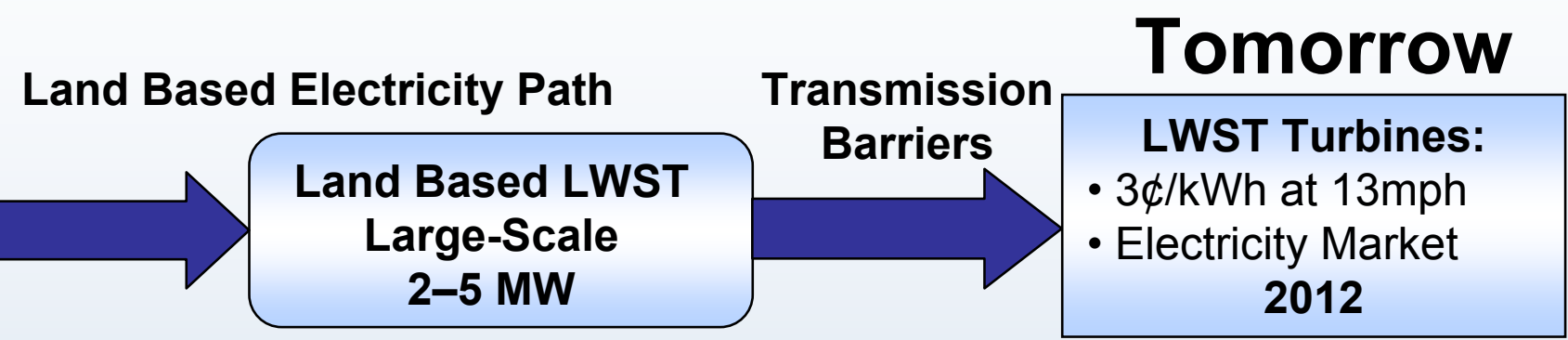

Offshore Electricity Path

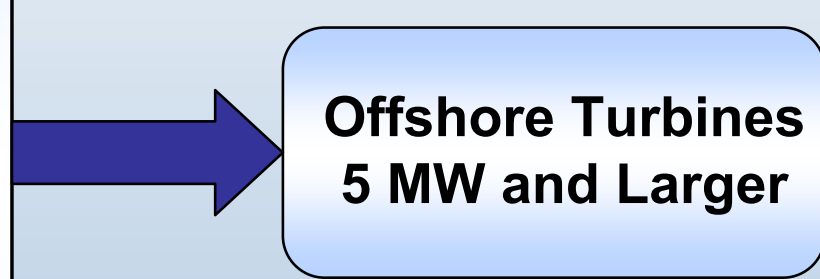

Cost \& Regulatory

Barriers

Offshore LWST Turbine:

- 5 cents/kWh

- Shallow/Deep water

- Electricity Market

- Higher wind Sites 2012 and Beyond
Advanced Applications Path

Cost \& Infrastructure

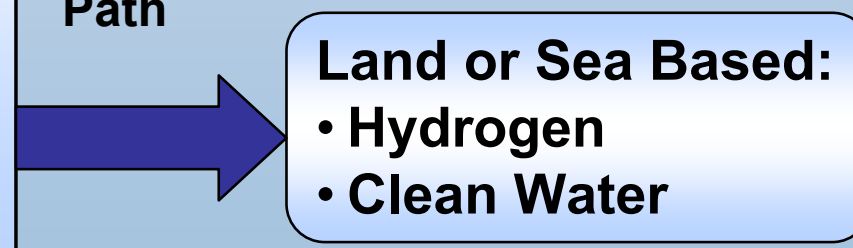

Barriers

Custom Turbines:

- Electricity

- $\mathrm{H} 2$ production

- Desalinate water

- Storage

- Multi-Market 2030 and Beyond 


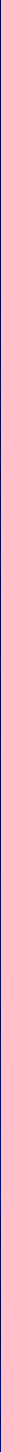

Roadmap case for grid-connected solar system with 30-year lifetime (customer side of meter)

*2004 electricity cost is based on present federal policies, investment tax credit, and accelerated depreciation. 


\section{The Biorefinery: The Path Ahead}

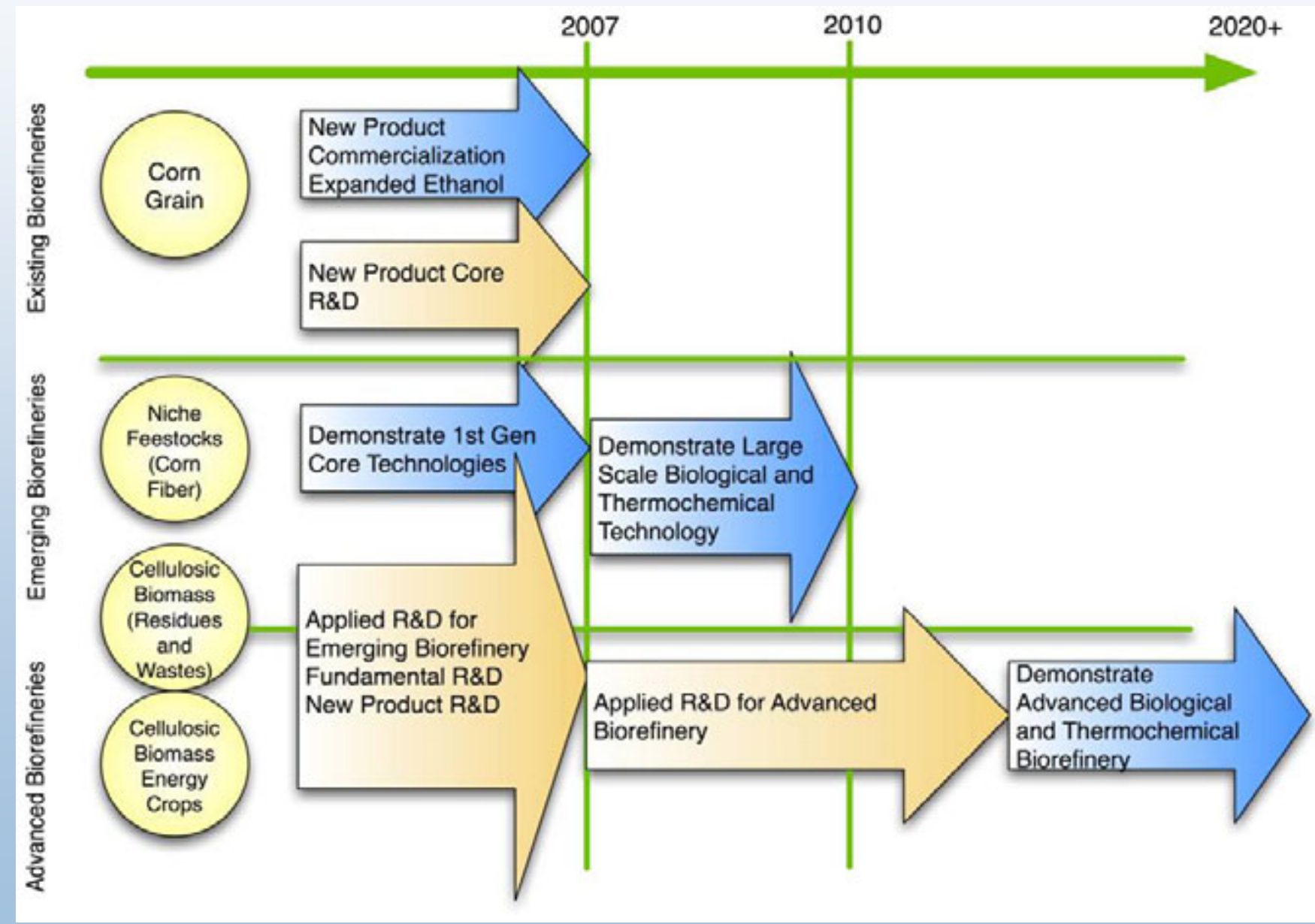

- A diverse feedstock supply that provides over 1 billion tons of biomass per year

- Equivalent of 3.5 billion barrels of crude oil per year or $55 \%$ of current U.S. petroleum demand 


\section{Technologies}

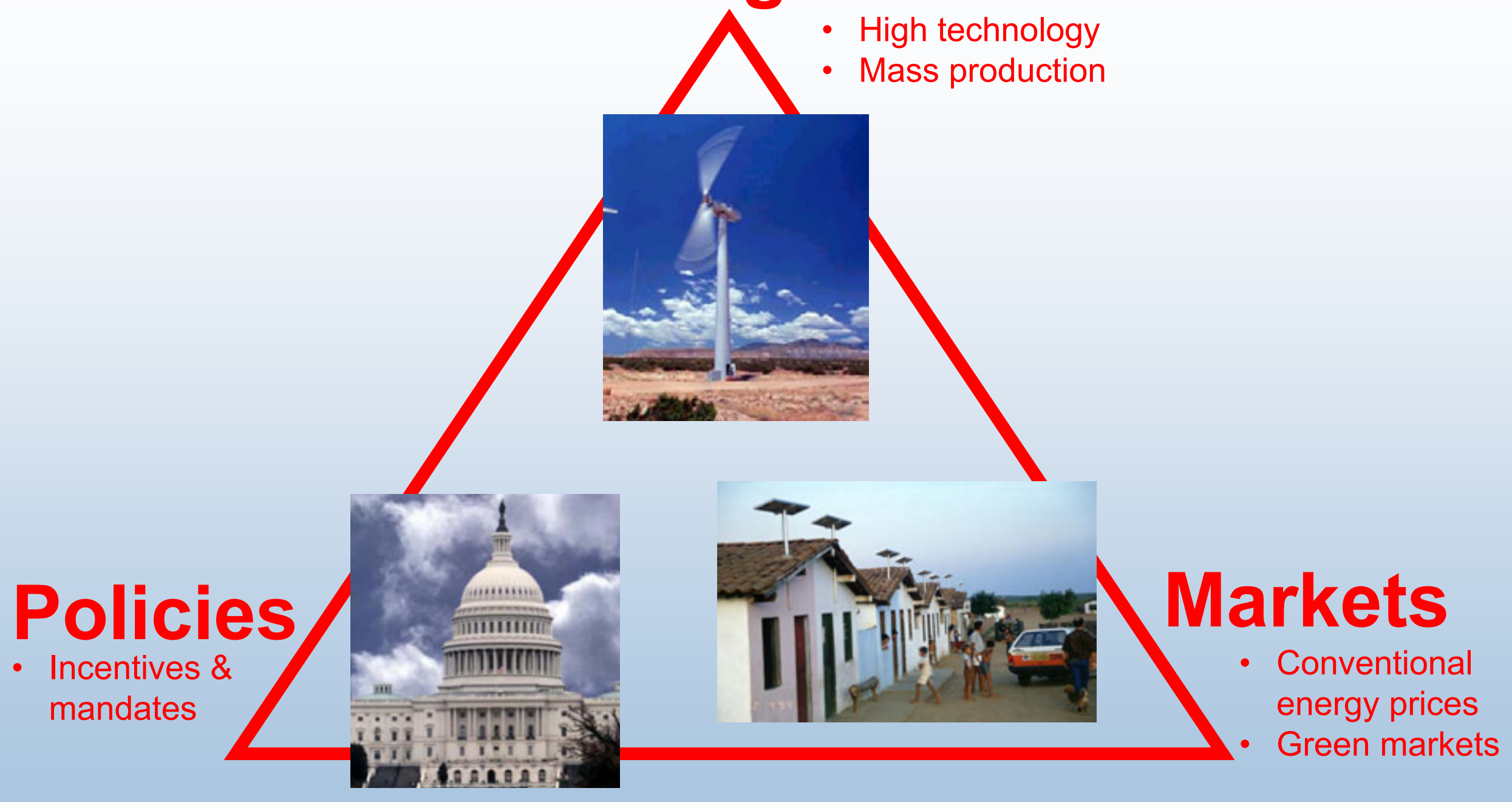


The U.S. Department of Energy's

National Renewable Energy Laboratory

www.nrel.gov

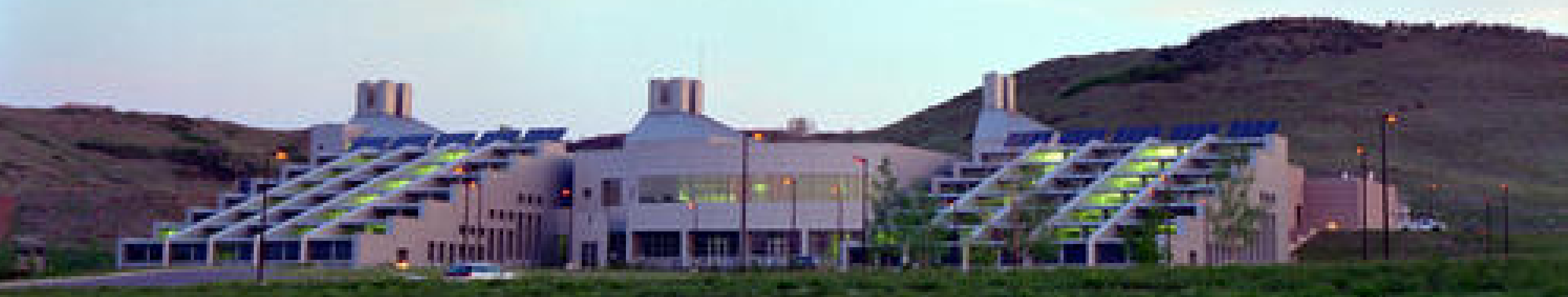

\author{
Golden, Colorado
}

